\title{
IJMR
}

International Journal of Microbiology Research

ISSN: 0975-5276 \& E-ISSN: 0975-9174, Vol. 3, Issue 2, 2011, pp-108-119

Available online at http://www.bioinfo.in/contents.php?id=27

\section{ISOLATION, MOLECULAR IDENTIFICATION AND OPTIMIZATION OF FERMENTATION PARAMETERS FOR THE PRODUCTION OF L-ASPARAGINASE, AN ANTICANCER AGENT BY FUSARIUM EQUISETI}

\author{
HOSAMANI R. ${ }^{1}$ AND KALIWAL B.B. ${ }^{{ }^{*}}$ \\ 1Department of Microbiology, University College of Science, Tumkur University, Tumkur, 572103, India \\ 2P.G. Department of Microbiology \& Biotechnology, Karnatak University, Dharwad, 580008, India \\ *Corresponding Author: Email- b_kailwal@yahoo.com
}

Received: August 06, 2011; Accepted: September 02, 2011

\begin{abstract}
L-asparaginase (L-asparagine amido hydrolase, E.C.3.5.1.1) is an extra cellular enzyme that has received considerable attention since it is used as an anticancer agent. In the present study, the fungal isolates from rhizosphere soils were screened for the L-asparaginase production by using modified Czapek Dox agar containing L-asparagine and phenol red as indicator. The strain isolated from rhizosphere soil of Ipomoea muricata showed the maximum zone diameter of $1.05 \mathrm{~cm}$. The $16 \mathrm{~s}$ rDNA sequence analysis indicated that the strain was most closely related to Fusarium equiseti. Various physical and chemical parameters were optimized under solid state fermentation (SSF) for L-asparaginase production. Further, it was observed that maximum activity of $3.26 \mathrm{IU}$ was achieved by employing soya bean meal as substrate, with incubation period of $48 \mathrm{hrs}$ and incubation temperature at $45^{\circ} \mathrm{C}$ at $\mathrm{pH} 7$ with di potassium hydrogen phosphate and manganese as the best phosphate and metal ion source respectively.
\end{abstract}

Keywords- L-asparaginase, Fusarium equiseti, rhizosphere soil, filamentous fungi, Ipomoea muricata, Optimization parameters, Solid state fermentation

\begin{abstract}
Introduction
L-asparaginase (L-asparagine amidohydrolase; E.C.3.5.1.1) is an extracellular enzyme used as an anticancer agent. L-asparaginase was introduced in the therapeutics due to the fact that in a significant number of patients with acute leukemia, particularly lymphocytic, the malignant cells are dependent on an exogenous source of L-asparagine for survival. Normal cells, however, are able to synthesize L-asparagine and thus are less affected by its rapid depletion produced by treatment with the enzyme L-asparaginase. The most common therapeutic indications of L-asparaginase are: treatment of Hodgkin's disease, treatment of acute lymphocytic leukemia mainly in children, acute myelocytic leukemia, acute myelomonocytic leukemia and chronic lymphocytic leukemia, lymphosarcoma treatment and melanosarcoma [1-7].

Asparaginases are found in diverse sources in nature, including bacteria, yeasts, molds, plants and vertebrates. The enzymes derived from microorganisms are the major sources of enzymes for practical and clinical use [8]. Commercially used enzymes are obtained from $E$. coli and Erwinia carotovora [9]. In many countries, asparaginase from only one of these sources is available for front-line therapy of lymphoblastic malignancies. There are other bacteria also which are now found to produce L-asparaginase such as Pseudomonas stutzeri MB-405 [10], Thermus thermophilus [11], Pseudomonas
\end{abstract}

aeruginosa 5007 [12], Staphylococcus sp.-6A [13], Bacillus circulans MTCC 8574 [14] and Serratia marcescenes SB08 [15]. However L-asparaginase from bacterial origin can cause hypersensitivity in long term use leading to allergic reactions and anaphylaxis [16]. The search for the other eukaryotic microorganisms can lead to an enzyme production with less adverse effects. It has been observed that eukaryotic microorganisms like yeast and filamentous fungi genera such as Aspergillus, Penicillum and Fusarium are commonly reported in scientific literature to produce L-asparaginase with less adverse effects [17-20]. Therefore, in the present study an attempt has been made to isolate the filamentous fungi from rhizosphere soils, molecular identification and optimization of L-asparaginase production by Fusarium equiseti.

\section{MATERIALS AND METHODS}

Isolation of filamentous fungi

Soil samples were collected from the rhizosphere of different plants at various locations around Karnataka University Dharwad campus. The fungi were isolated by plating serially diluted sample on Czapek-Dox agar, $\mathrm{pH}$ 6.2. Individual colonies were regrown at $28^{\circ} \mathrm{C}$ for obtaining pure culture. 


\author{
Screening of L-asparaginase producer by plate \\ assay
}

The isolated colonies were screened for L-asparaginase production on modified Czapek-dox agar [21] containing g/l of distilled water: Glucose,2.0; L-asparagine,10.0; $\mathrm{KH}_{2} \mathrm{PO}_{4}, 1.52 ; \quad \mathrm{KCl}, 0.52 ; \quad \mathrm{MgSO}_{4} .7 \mathrm{H}_{2} \mathrm{O}, 0.52$; $\mathrm{CuNO}_{3} .3 \mathrm{H}_{2} \mathrm{O}$,trace; $\quad \mathrm{ZnSO}_{4} .7 \mathrm{H}_{2} \mathrm{O}$, trace; $\mathrm{FeSO}_{4}, 7 \mathrm{H}_{2} 0$,trace; Agar,18.0, pH 6.2 and this media was supplemented with phenol red $0.009 \%(\mathrm{v} / \mathrm{v})$ [22] and incubated at $28^{\circ} \mathrm{C}$ for $96 \mathrm{hrs}$. Control plates were of modified Czapek-Dox's medium without dye and without L-asparagine. The zone and colony diameter were measured after 48 hours. Colonies with pink zones around the colony were considered as L-asparaginase producing strains. The broth studies were carried out in order to compare the results obtained with the positive isolates for plate assay. The isolate with highest zone of clearance was sent to Agharkar Research Institute, Pune for molecular identification. The sequence obtained was analyzed by using nBLAST at NCBI (http://ncbi.nlm.nih.gov/blast.cgi). Further fermentation studies were carried out with the same isolate.

\section{Optimisation of fermentation parameters}

The production of L-asparaginase by Fusarium equiseti under solid state fermentation conditions mainly depends on various factors like substrate selection, temperature, initial $\mathrm{pH}$, phosphate source and metal ions. In order to achieve optimized activity under SSF conditions each parameter is varied one at a time. All experiments were conducted in five replicates and the mean values were presented.

\section{Effect of various substrates}

Seven different substrates such as fruit wall of Spathodea companulata, Acacia concinna, Pletophorum ptericarpum, Poincia regia, agro wastes such as Soya bean meal, jowar bran and sugar cane bagasse were assessed for the production of L-asparaginase. The best solid substrate is selected for further optimization studies.

\section{Effect of initial temperature}

The effect of temperature was studied by cultivating Fusarium equiseti on $10 \mathrm{gm}$ of soya bean meal and the flasks were incubated at $10,25,37,45$ and $55^{\circ} \mathrm{C}$ respectively for 48 hours and enzyme assay was carried out as described by Imada et al., [23].

\section{Effect of initial $\mathrm{pH}$}

To determine initial $\mathrm{pH}, 10 \mathrm{gm}$ of Soy bean meal was taken in different Erlenmeyer flasks moistened with $70 \%$ moisture and $\mathrm{pH}$ were varied in the range of 4-7 by using $1 \mathrm{~N} \mathrm{NaOH}$ and $1 \mathrm{~N} \mathrm{HCl}$. Fusarium equiseti was inoculated and incubated at $45^{\circ} \mathrm{C}$ for 48 hours.

\section{Effect of phosphate source}

Various phosphate sources like di-potassium hydrogen phosphate, potassium di-hydrogen phosphate and diammonium hydrogen phosphate and $0.25-1.25 \%$ with
$0.25 \%$ increment in concentration were supplemented to the substrate and further enzyme activity was carried out by extracting the fermented substrate.

\section{Effect of metal ions}

To determine the effect of various metal ions, the substrate was incorporated with metal ions such as $\mathrm{Mn}^{2+}$, $\mathrm{Zn}^{2+} \cdot \mathrm{Mg}^{2+}$ and $\mathrm{Cu}^{2+}$ respectively at the concentration of $0.01-0.03 \%$ and the flasks were incubated at $45^{\circ} \mathrm{C}$ for 48 hours. After incubation enzyme activity was carried out.

\section{Extraction of fermented substrates}

One gm of fermented substrate was taken out periodically every 24 hours in aspetic conditions and phosphate buffer $(1: 10)$ was added to it. The contents of the flasks were kept shaking and the homogenized sample were filtered and centrifuged. The supernatant was used to carry out the enzyme assay.

\section{Quantitative assay of L-asparaginase activity}

Quantitative estimation was carried out following Nessler's reagent according to the method of Imada et al., [23]. The reaction mixture containing $0.5 \mathrm{ml}$ of $0.04 \mathrm{M}$ L-asparagine, $0.5 \mathrm{ml}$ of $0.5 \mathrm{M}$ phosphate buffer $(\mathrm{pH} 7.8)$, $0.5 \mathrm{ml}$ of an enzyme and $0.5 \mathrm{ml}$ distilled water was added to make up the total volume to $2 \mathrm{ml}$. The tubes were incubated at $30^{\circ} \mathrm{C}$ for 30 minutes. The reaction was stopped by adding $0.5 \mathrm{ml}$ of $1.5 \mathrm{M}$ Trichloroacetic acid (TCA). The blank was prepared by adding enzyme after the addition of TCA. To the $3.7 \mathrm{ml}$ of distilled water and $0.2 \mathrm{ml}$ of Nessler's reagent $0.1 \mathrm{ml}$ from the above mixture was added. After incubating the mixture at $20^{\circ} \mathrm{C}$ for 20 minutes the OD was checked at $450 \mathrm{~nm}$ with Spectrophotometer [Systronics]. The enzyme activity was expressed in International unit.

\section{International unit}

One IU of L-asparaginase activity was defined as that amount of enzyme which catalyses the formation of $1 \mu$ mole of $\mathrm{NH}_{3}$ per minute under the optimal assay conditions.

\section{Results \\ Isolation and screening}

In the present study isolation and screening of filamentous was carried out. The screening was done based on the zone of clearance as per Gulati et al., [22] method. The results revealed that out of twenty one isolates from different rhizosphere soils, the four positive potential strains show different range of zone of diameter. The isolate BBK9 from rhizosphere soil of Ipomoea muricata exhibited the highest zone (Fig. 1) of diameter of $1.05 \mathrm{~cm}$ than compared to be BBK14 which showed zone diameter of $0.86 \mathrm{~cm}$, BBK20 showed 0.84 $\mathrm{cm}$ and BBK3 showed $0.52 \mathrm{~cm}$ respectively (Table. 1). Lasparaginase activity was $0.14 \mathrm{IU}$ and $\mathrm{pH}$ was 8.54 in the broth containing the isolate BBK9 followed by BBK20 which showed the activity of $0.06 \mathrm{IU}$ and $\mathrm{pH}$ of 8.43 , BBK3 showed the activity of $0.04 \mathrm{IU}$ and the $\mathrm{pH}$ was 8.10 respectively (Table.1). Therefore, the isolate BBK9 
from the rhizosphere soil of Ipomoea muricata showed the highest zone diameter and maximum activity, was sent to Agharkar Research Institute, Pune for molecular identification. Phylogenetic analysis based on 16s rRNA gene sequencing showed that the isolate was grouped into the genus Fusarium equiseti with Score $=1397$ bits (756), Expect $=0.0$ Identities $=763 / 766(99 \%)$, Gaps $=$ $1 / 766(0 \%)$ Strand=Plus/Minus. The phylogenetic tree obtained by $\mathrm{nBLAST}$ analysis is presented in the Fig. (2).

\section{Optimization of fermentation parameters Substrates}

In Solid State Fermentation selection of suitable solid substrate for the fermentation is the critical factor. In the present study seven different substrates viz., Spathodea companulata, Acacia concinna, Pletophorum ptericarpum, Poincia regia, agro wastes such as Soya bean meal, jowar bran and sugar cane bagasse were assessed for the production of L-asparaginse by Fusarium equiseti (Fig. 3). High titre of 3.26 IU was obtained in the medium containing soya bean meal while jowar bran showed $1.2 \mathrm{IU}$, sugar cane bagasse showed 0.21 IU Acacia concinna 0.13 IU, Poincia regia showed $0.11 \mathrm{IU}$, Spathodea companulata showed $0.52 \mathrm{IU}$ and Pletophorum ptericarpum showed 0.45 IU respectively. As maximum activity was seen using soya bean meal therefore, it was selected for further fermentation studies.

\section{Temperature}

Temperature is also one of the critical factors which have to be optimized. In order them to find out the optimum temperature on the fermentation, Fusarium equiseti was incubated at various temperature range such as 10, 25, 37,45 and $55^{\circ} \mathrm{C}$ keeping other conditions at their optimum levels. Highest activity was observed at $45^{\circ} \mathrm{C}$ which showed $6.85 \mathrm{IU}$ at $48 \mathrm{hrs}$ followed by $37^{\circ} \mathrm{C}$ with activity of $5.38 \mathrm{IU}, 55^{\circ} \mathrm{C}$ with maximum activity of 5.02 $\mathrm{IU}, 25^{\circ} \mathrm{C}$ with maximum activity of $3.61 \mathrm{IU}$ where as lowest enzyme was produced at $10^{\circ} \mathrm{C}$ with maximum activity of $2.80 \mathrm{IU}$ respectively (Fig. 4).

\section{$\mathrm{pH}$}

Initial $\mathrm{pH}$ level of substrate plays crucial role for the successful L-asparaginase production under Solid state fermentation conditions. The fermentative medium $\mathrm{pH}$ was adjusted accordingly with $1 \mathrm{~N} \mathrm{HCI} / \mathrm{NaOH}$ from $4-10$. Maximum production of L-asparaginase $5.82 \mathrm{IU}$ at 48 hours was found with a $\mathrm{pH}$ of 7.0 . It was followed by $\mathrm{pH}$ 8 with maximum activity of $5.36 \mathrm{IU}, \mathrm{pH} 6$ with maximum activity of $5.33 \mathrm{IU}, \mathrm{pH} 5$ with activity of $5.22 \mathrm{IU}, \mathrm{pH} 9$ with $4.8 \mathrm{IU}, \mathrm{pH} 4$ with $4.66 \mathrm{IU}$ and $\mathrm{pH} 10$ with $4.32 \mathrm{IU}$ respectively (Fig. 5).

\section{Phosphate source}

Phosphate is also one of the essential factors in the metabolism which has to be optimized. Different phosphate sources such as di-potassium hydrogen phosphate, potassium di-hydrogen phosphate and diammonium hydrogen phosphate with the concentration of $0.25 \%-1.25 \%$ were taken for the present study. The data reveals that maximum activity of $6.21 \mathrm{IU}$ was obtained for $0.5 \%$ Di-potassium hydrogen phosphate and the least activity was $4.27 \mathrm{IU}$ for $1.25 \%$ di-potassium hydrogen phosphate followed by potassium di hydrogen phosphate with the maximum activity of $4.21 \mathrm{IU}$ at $0.75 \%$ and the least activity of $3.42 \mathrm{IU}$ at $1.25 \%$. Similarly maximum activity of $4.13 \mathrm{IU}$ was obtained with $0.5 \%$ diammonium hydrogen phosphate and the least activity of 3.12 IU was obtained with $1.25 \%$ (Fig. 6, 7 and 8). From the present results it is clear that di-potassium hydrogen phosphate is the best phosphate source which can be used for L-asparaginase production.

\section{Metal ions}

Certain metal ions are essential for cell mass formation and also act as a co-factor for several biosynthetic enzymes. Metal ions such as $\mathrm{Mn}^{2+}, \mathrm{Zn}^{2+}, \mathrm{Mg}^{2+}$ and $\mathrm{Cu}^{2+}$ respectively at the concentration of $0.01-0.03 \%$ were taken for the present study. The maximum activity of 5.21 IU was obtained for $0.01 \%$ of $\mathrm{Mn}^{2+}$ and least activity of $4.21 \mathrm{IU}$ for $0.03 \% \mathrm{Mn}^{2+}$ followed by $\mathrm{Zn}^{2+}$ with activity of $4.94 \mathrm{IU}$ and least activity of $4.03 \mathrm{IU}$, for $\mathrm{Mg}^{2+}$ $4.42 \mathrm{IU}$ and the least activity of $3.41 \mathrm{IU}$. For $\mathrm{Cu}^{2+}$ the maximum activity was $3.42 \mathrm{IU}$ at $0.01 \%$ and the least activity was $2.74 \mathrm{IU}$ at $0.03 \%$ was obtained (Fig. 9, 10, 11 and 12).

\section{Discussion}

Out of twenty one isolates collected from different rhizosphere soils, the four isolates showed positive for Lasparaginase production by producing pink coloration around the colony. The control showed no colour change. Among various filamentous fungi tested by plate assay and broth studies the isolate BBK9 from the rhizosphere soil of Ipomoea muricata exhibited the zone of diameter $1.05 \mathrm{~cm}$, activity of $0.14 \mathrm{IU}$ and $\mathrm{pH}$ of the broth was 8.83. It is proposed that strain exhibiting zone of diameter above $0.9 \mathrm{~cm}$ are referred as good Lasparaginase producers, those strains with zone diameter of $0.6-0.9 \mathrm{~cm}$ and those having below $0.6 \mathrm{~cm}$ zone diameter may be referred to as moderate and poor L-asparaginase producers respectively. Phylogenetic analysis based on 16s rRNA gene sequencing and the sequence consisting of 766 nucleotides was submitted to the GenBank (National Centre for Biotechnological Information, USA, accession number JN400528). The sequence data showed that the isolate BBK9 has highest sequence similarity (99\%) with the genus Fusarium equiseti. Hence it is concluded that the strain BBK9 belongs to the genus Fusarium equiseti. In the rhizosphere soil, root exudates are the natural source of amino acid for microorganisms, which may enhance the L-asparaginase biosynthesis.

Gupta et al., [24] have reported rhizosphere soil of mangrove plant isolate Fusarium FMG 13 was able to produce L-asparaginase. L-asparaginase production by actinomycetes isolated from rhizosphere soils of lemon grass (Cymbopogon citratus) have been reported by Sutthinan et al., [25]. In the present study it is clear that filamentous fungi from rhizosphere have shown to 
produce extracellular L-asparaginase. It is reported for the first time that Fusarium equiseti isolated from the rhizosphere soil of Ipomoea muricata is known to produce L-asparaginase.

Solid substrate fermentation (SSF) has emerged as an effective technique to increase the product yield at low capital cost, low energy requirement, less water output and substrate itself acts as carbon or energy source. In addition employing natural substrates serve as solid support [26]. In the present study seven different substrates viz., fruit wall of Spathodea companulata, Acacia concinna, Pletophorum ptericarpum and Poincia regia. Agro wastes such as Soya bean meal, jowar bran and sugar cane bagasse were assessed for the production of L-asparaginse by Fusarium equiseti. Soya bean meal proved to be the best substrate for Lasparaginase production. Mishra [27] who have reported bran of Glycine max used as sole source for growth in SSF have shown the maximum enzyme production using Aspergillus niger. Production of L-asparaginase was also carried out using soya bean meal as substrate under SSF conditions by Pseudomonas aeruginosa 50071 [12]. SSF is more advantageous over submerged fermentation $(\mathrm{SmF})$ as it is less sensitive to contamination than SmF [28]. The process is more appropriate for developing countries [29]. In SSF selection of suitable solid substrate for the fermentation is the critical factor.

Temperature is one of the critical factors which have to be optimized. In order to find out the optimum temperature for the fermentation Fusarium equiseti was incubated at various temperatures and the effect was studied. The results indicated that $45^{\circ} \mathrm{C}$ was optimum temperature for L-asparaginase production (6.85 IU). Any temperature beyond the optimum range is found to have an adverse effect on the metabolic activities of microorganisms and it is also reported that metabolic activities become slower at lower temperature [30]. Mishra [27] who have reported the highest activity of $40.9 \mathrm{U} / \mathrm{gds}$ at $30^{\circ} \mathrm{C}$ where as Maladkar et al., [31] have reported the optimum activity at $50^{\circ} \mathrm{C}$. The thermostable asparaginase from T.aquaticus had an optimum temperature of $75^{\circ} \mathrm{C}$ have been reported by Curran et al., [20].

Initial $\mathrm{pH}$ level of substrate plays key role for the successful L-asparaginase production under solid state fermentation conditions. In order to find out there optimum $\mathrm{pH}$ for the L-asparaginse production, the initial $\mathrm{pH}$ of the fermentation medium was adjust to different levels and fermentation was carried out at $45^{\circ} \mathrm{C}$. The data revealed that $\mathrm{pH} 7$ was suitable for maximum production of L-asparaginase by Fusarium equiseti with soybean meal as substrate. The fermentation efficiency was maximum at $\mathrm{pH} 7$ by Streptomyces plicatus [32] while Narayan et al., [33] have reported the maximum Lasparaginase production at $\mathrm{pH} 7.5$ by S.albidoflavus and Siddalingeshwara et al., [34] have reported the maximum activity of $5.21 \mathrm{IU}$ at $\mathrm{pH} 4.5$. The present results correlate with De Angeli et al., [17] who have reported pH 7 as optimum for the production of L-asparaginase under submerged fermentation process.

Phosphate is required in certain amount for growth and metabolism. In secondary metabolic process they have lower tolerance range to in organic phosphate than the vegetative growth. Phosphate also plays key role in the regulation of the enzymes. From the present study Dipotassium hydrogen phosphate was the best phosphate source for L-asparaginase production. Mukherjee et al., [35] have also reported the maximum activity for $0.1 \%$ dipotassium hydrogen phosphate and $0.16 \%$ diammonium hydrogen phosphate under submerged conditions using Enterobacter aerogenes where as Venil and Lakshmanaperumalasamy [15] have reported potassium di-hydrogen phosphate the best source for Lasparaginase production by Serratia marcescens.

Certain trace elements like mangenese, zinc, magnesium, copper, calcium, sodium and iron are needed in appropriate concentrations and must be added to the fermentation medium. As they are essential for cell mass formation as well as they is acting as a cofactor for several biosynthetic enzymes. In the present study $0.01 \%$ mangenese was the best metal ion source for L-asparaginase production and the least activity was obtained with copper. Borkotaky and Bezbaurauh [36] have reported that enzyme activity was not inhibited by $10 \mathrm{mmol} / \mathrm{L}$ metal ions such as $\mathrm{Na}^{2+}, \mathrm{K}^{+}, \mathrm{Mg}^{2+}, \mathrm{Zn}^{2+}, \mathrm{Ca}^{2+}$, $\mathrm{Co}^{2+}, \mathrm{Ba}^{2+}$ and $\mathrm{Ni}^{2+}$. Alexander et al., [37] have reported that copper acts as co-factor for the reaction. The present results were in good agreement with Robinson and Berk [38] who have reported the supplementation of metal ions like copper, zinc and manganese to the $\mathrm{H} 82$ medium in the concentration ranging from $0.001-0.002 \%$ and obtained maximum L-asparaginase production 1.73 , 1.74 and $1.71 \mathrm{IU}$ by supplementation of $0.001 \%$ concentration of copper, zinc and manganese respectively.

\section{Conclusion}

From the observations carried out clearly indicate that Fusarium equiseti isolated from rhizosphere soil of Ipomoea muricata has the ability to produce significant amount of L-asparaginase enzyme. This is the first report about Fusarium equiseti from the rhizosphere soil of Ipomoea muricata to produce L-asparaginase. Fermentation studies carried out indicate that solid state fermentation process is an efficient and economically viable bioprocess for the production of L-asparaginase especially in the developing countries.

Critical factors influence the selection of asparaginase as a therapeutant such as substrate, temperature, $\mathrm{pH}$, phosphate and metal ions. The present study indicates that large quantities of the enzyme with highest activities reported can be obtained using soya bean meal as substrate at $45^{\circ} \mathrm{C}$ at $\mathrm{pH} 7$ with di-potassium hydrogen phosphate and manganese as the best metal ion source which makes it attractive for further optimization and characterisation studies. 


\section{Acknowledgment}

The authors are grateful to P.G. Department of Studies in Microbiology and Biotechnology for providing necessary facilities to carry out the research work.

\section{References}

[1] Cunningham I., Gee T., Dowling M., Chaganti R., Bailey R., Hopfan S., Bowden L., Turnbull A., Knapper W. and Clarkson B. (1979) Blood, 53, 375-395.

[2] Levine A.M., Forman S.J., Meyer P.R., Koehler S.C., Liebman H.,Paganini-Hill A., Pockros A., Lukes R.J. and Feinstein D.I. (1983) Blood, 61, 92-98.

[3] Capizzi R.L., Bertino G. and Handschumacher R.E. (1970) Ann Rev Med, 21, 433-434.

[4] Ravindranath Y., Abella E., Krischer J.P., Wiley J., Inoue S., Harris M., Chauvenet A., Alvarado C.S., Dubowy R., Ritchey A.K., Land V., Stueber C.P. and Weinstein H. (1992) Blood, 80, 2210-2214.

[5] Mitchell L., Hoogendoorn H., Giles A.R., Vegh P. and Andrew M. (1994) Blood, 83, 386-391

[6] Klumper E., Pieters R., Veerman A.J., Huismans D.R., Loonen A.H.,

[7] Hahlen K., Kaspers G.J., Van Wering E.R., Hartmann R. and Henze G. (1995) Blood, 86, 3861-3868.

[8] Larson R.A., Dodge R.K., Burns C.P., Lee E.J., Stone R.M., Schulman P., Duggan D., Davey F.R., Sobol R.E. and Frankel S.R. (1995) Blood, 85, 2025-2037.

[9] Northrup N.C., Rassnick K.M., Snyder I.A., Stone M.S., Cotter S.M., Moone A.S. (2002) Journal of veterinary internal medicine, 16, 570-575.

[10] Marlborough D.I., Miller D.S. and Cammack K.A. (1975) Biochim. Biophys. Acta, 386, 576589.

[11] Manna S., Sinha A., Sadhukhan R. and Chakrabaty S. L. (1995) Curr. Microbiol, 30, 291-298.

[12] Prista A. A. and Kyridio D. A. (2001) Mol. Cell.Biochem, 216, 93-101.

[13] El-Bessoumy A. A, Sarhan M. and Mansoor J. (2001) J. Biochem, Mol Biol. 37, 387-393.

[14] Prakasham R. S., Subba Rao C., Sreenivas Rao R., Suvarna Lakshmi G. and Sarma P. N. (2007) J. Appl. Microbiol, 102, 1382-1391.

[15] Hymathi M., Satish T., Ch Subba Rao and $\begin{array}{llll}\text { Prakasham R. } & \text { S. }\end{array}$ Appl.Biochem.Biotechnol, 159, 191-198.

[16] Venil C. and Lakshmanaperumalasamy $P$. (2009) The Internet Journal of Microbiology, 7(1), 10-18.
[17] Reynolds D., Taylor J.W. (1993) The Fungal Holomorph: A Consideration of Mitotic Meiotic and Pleomorphic Speciation, CAB International, Wallingford, UK.

[18] De-Angeli L.C., Pucchiari F., Russi S. and Tonolo A. (1970) Nature, 225, 550.

[19] Arima K., Sakamoto T., Araki C. and Tomura G. (1972) Agric. Biol. Chem, 36, 356-361.

[20] Nakhama K., Imada A., Igrasi S. and Tubaki K. (1973) J. Gen.Microbiol.75, 269-276

[21] Curran M.P., Daniel R.M., Guy R.G. and Morgan H.W. (1985) Arch Biochem Biophys, 241, 571-576.

[22] Saxena R.K. and Sinha U. (1981) Curr Sci, 50, 218-219.

[23] Gulati R., Saxena R. K. and Gupta R. Letters in Applied Microbiology, 1997, 24, 23-26.

[24] Imada A., Igarasi S., Nakahama K. and Isono M. Journal of General Microbiology, 1973, 76, 85-99.

[25] Gupta N., Dash S.J. and Basak U.C. (2009) AsPac.J.Mol.Biol.Biotechnol, 17(1), 27-30.

[26] Khamna S., Yokota A. and Lumyong S. (2009), International Journal of Integrative Biology, 6(1), 22-26.

[27] Pandey A., Soccol C.R, Roudriguez-Leon J.A and Nigam P. (2001) Asiatech. Publishers, New Delhi.

[28] Mishra A. (2006) Appl. Biochem. Biotechnol, $135,33-42$.

[29] Lonsane B. K., Ghildyal N. P., Budiatma S. and Ramakrishnan S. V. (1985) Enzyme Microb. Technol, 7, 228-256.

[30] Carrizales V. and Jaffe W. (1986) Interscience, 11, 9-15

[31] Rainbeut M. and Alazard D. (1980) Eur. J.Appl. Microbiol. Biotechnol, 9,199.

[32] Maladkar N. K., Singh V. K. and Naik S. R. (1993) Hidustan Antibiot. Bull, 35, 77-86.

[33] Koshy A., Dhevendaran K., Georgekutty M.I. and Natarajan P. (1997) Journal of Marine Biotechnology, 5, 181-185.

[34] Narayana K.J.P., Kumar, K.G., Vijayalakshmi M. (2008) Indian Journal of Microbiology, 48, $331-336$

[35] Siddalingeshwara K.G., and Lingappa K. (2010) an International Journal of Pharmaceutical Sciences, 1(1), 103-112.

[36] Mukherjee J., Majumdar S. and Scheper T. (2000) Appl Microbiol. Biotechnol. 53, 180-184.

[37] Borkotaky B. and Bezbereauh R.L. (2002) Folia microbiol, 47(5), 473-476.

[38] Charlson J., Coman J., Karossi A., Stephens S., Vagg S. and Watton C. (1978) Inorganica chimica Acta, 28, 217-222

[39] Robinson S.R. and Berk B. (1969) Biotech. Bioeng, 11, 1211. 


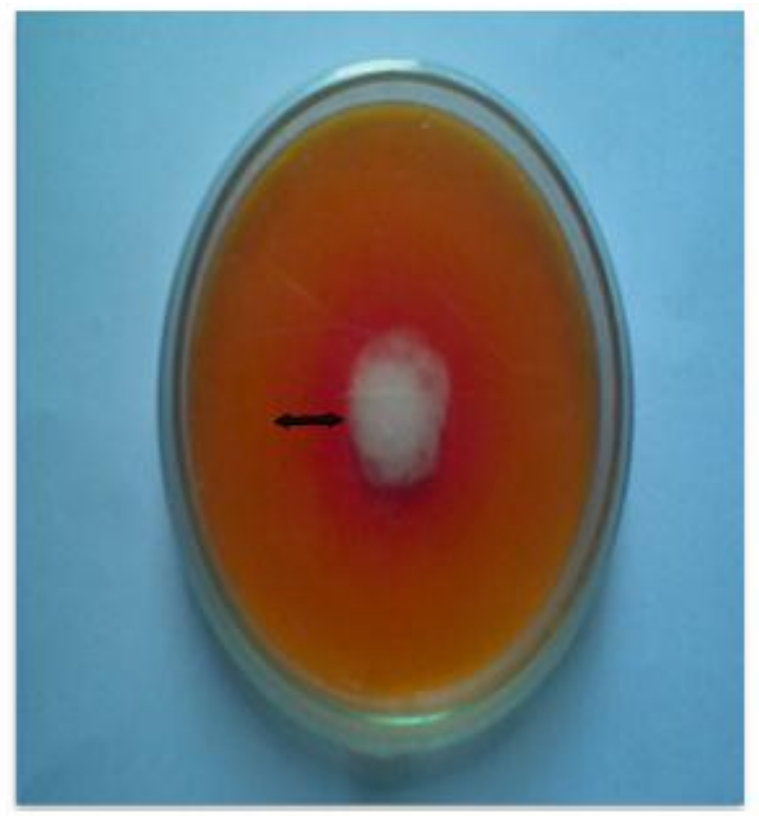

Fig. 1 Rapid Plate assay for the screening of $\mathrm{L}$-asparaginase producers

Table. 1 Colony diameter and zone diameter after 48 hrs and L-asparaginase activity with change in the $\mathrm{pH}$ of the cuiture filtrate

\begin{tabular}{|c|c|c|c|c|}
\hline $\begin{array}{l}\text { Isolate } \\
\text { No. }\end{array}$ & $\begin{array}{l}\text { Colony } \\
\text { diameter } \\
(\mathrm{cm})\end{array}$ & $\begin{array}{l}\text { Zone } \\
\text { Diameter } \\
(\mathrm{cm})\end{array}$ & $\begin{array}{l}\text { Enzyme } \\
\text { Activity } \\
\text { (IU/mi) }\end{array}$ & $\begin{array}{l}\mathrm{pH} \text { of } \\
\text { the } \\
\text { filtratet }\end{array}$ \\
\hline $\mathrm{BBK} 3$ & 1.34 & 0.52 & 0.04 & 8.10 \\
\hline BBK9 & 2.35 & 1.05 & 0.14 & 8.83 \\
\hline BBK14 & 1.57 & 0.86 & 0.07 & 8.70 \\
\hline BBK20 & 1.61 & 0.84 & 0.06 & 8.43 \\
\hline
\end{tabular}




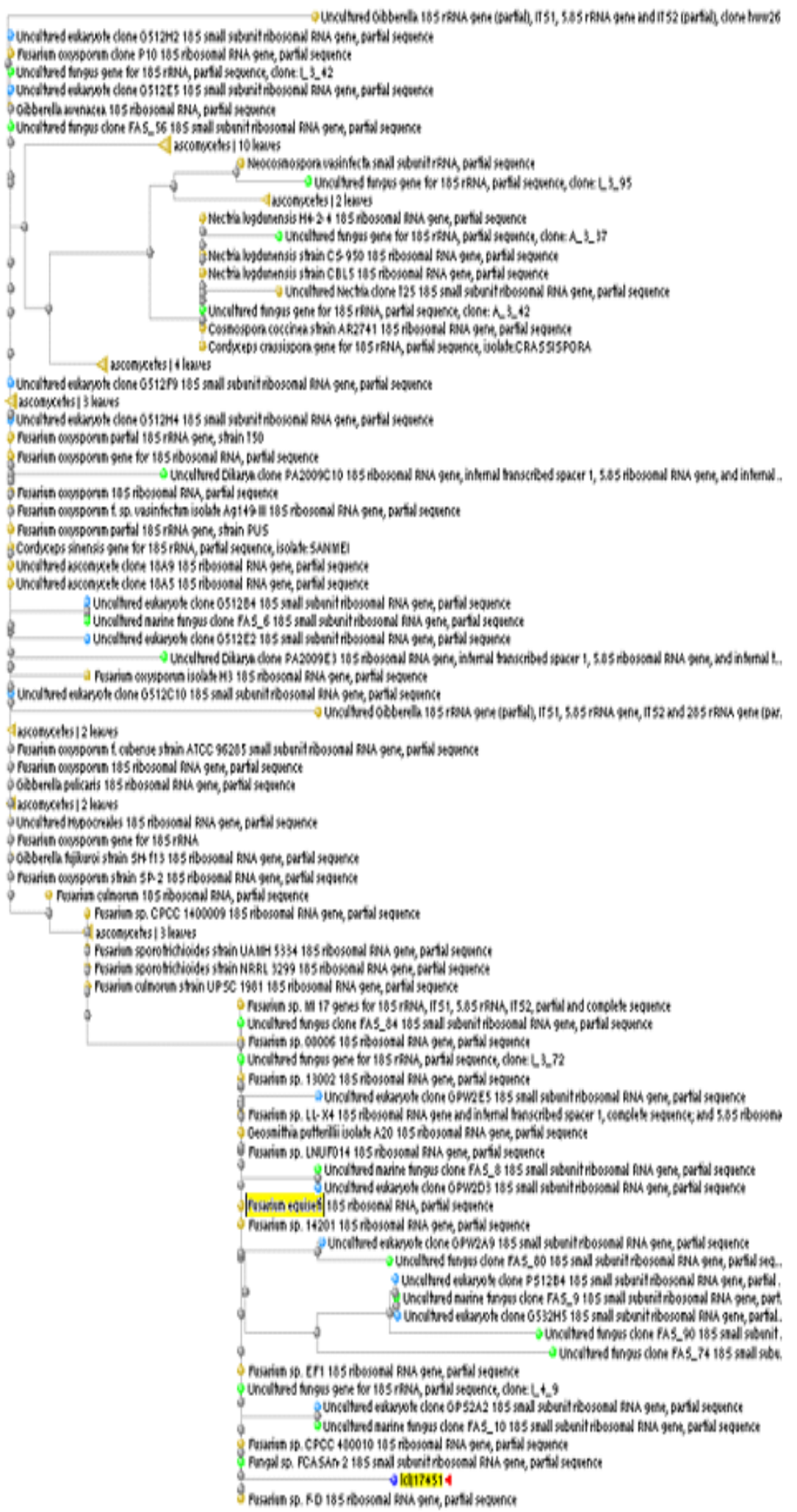

Fig. 2 showing the phylogentic tree obtained by $\mathrm{ABLAST}$ analysis of $16 \mathrm{~S} \mathrm{fDNA}$ 


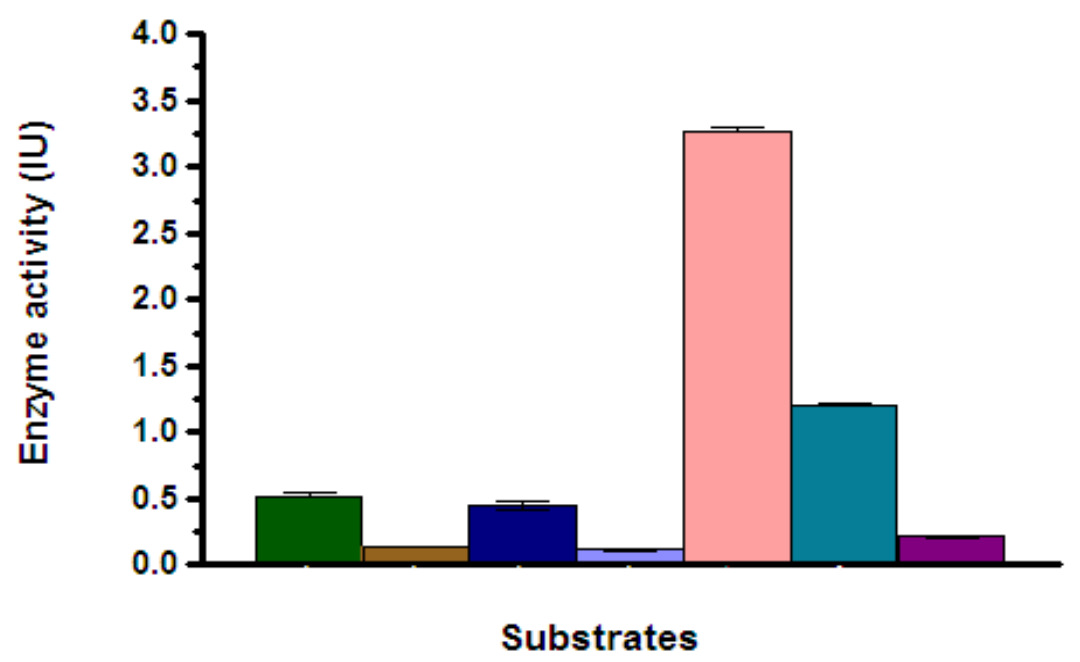

Fig. 3 Effect of different substrates on the production of L-asparaginase

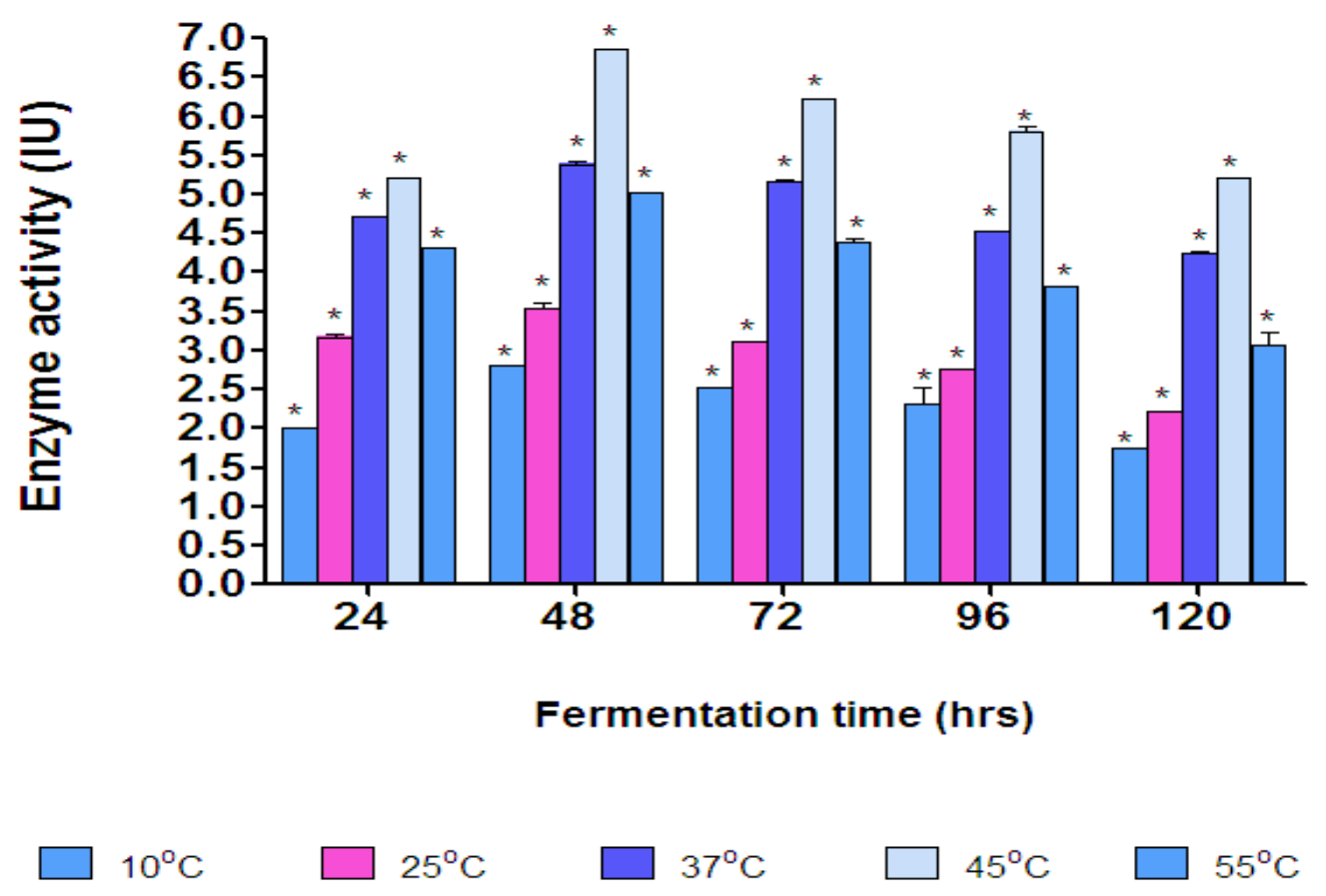

Fig. 4 Effect of temperature on the production of L-asparaginase 


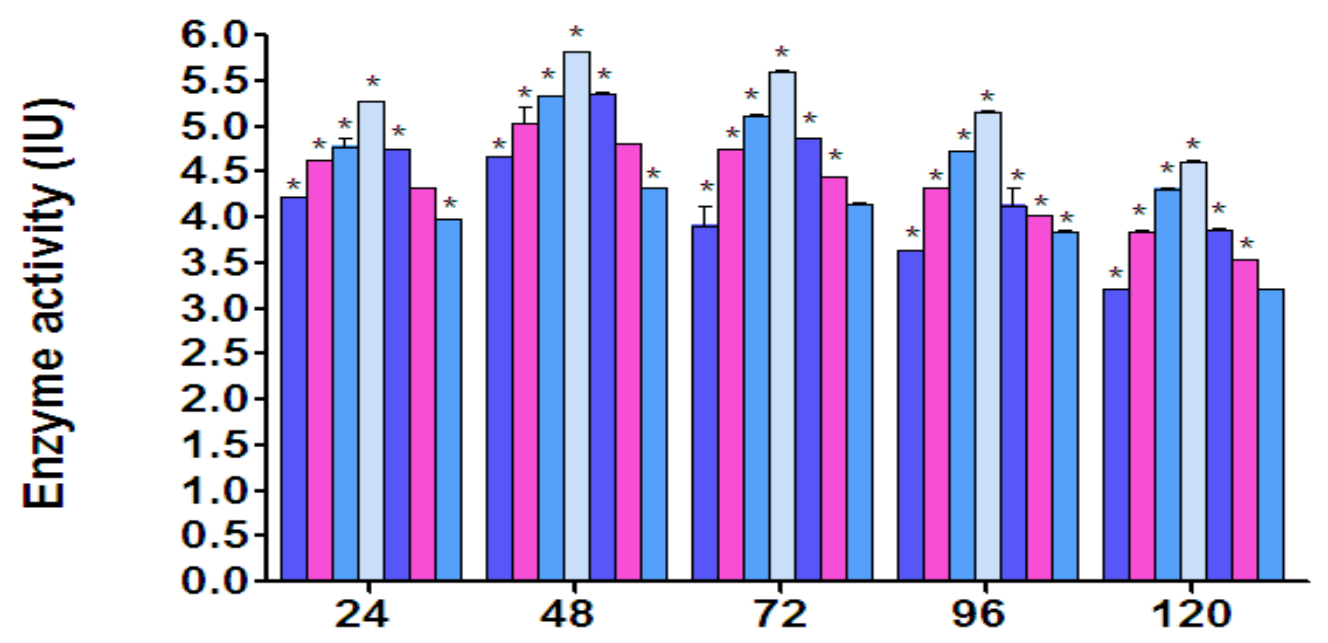

Fermentation time (hrs)

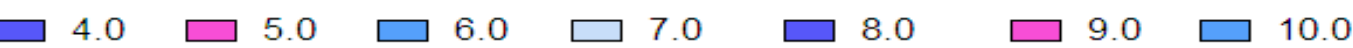

Fig. 5 Effect of $\mathrm{pH}$ on the production of L-asparaginase

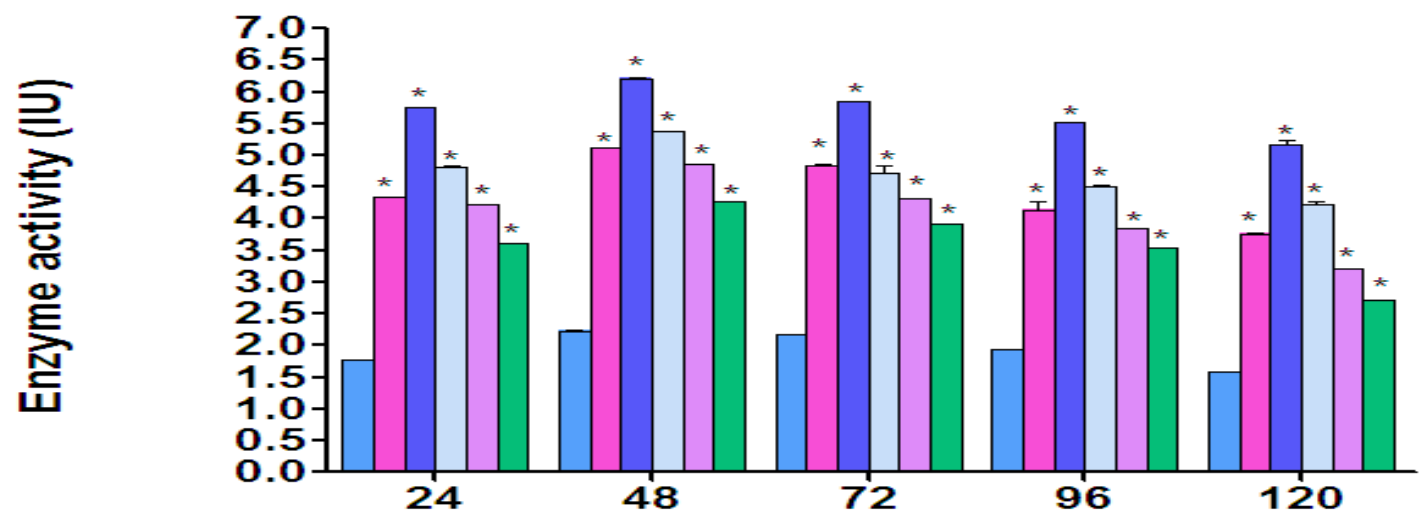

Fermentation time (hrs)

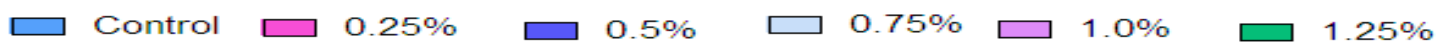

Fig. 6 Effect of Di-potassium hydrogen phosphate on the production of L-asparaginase 


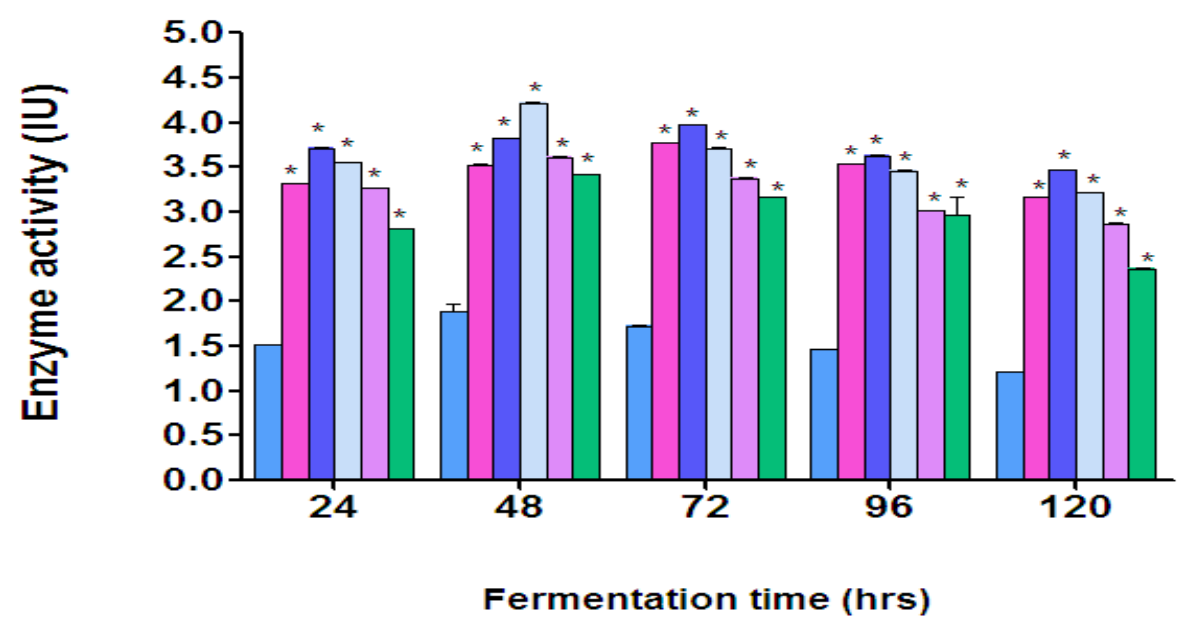

Control

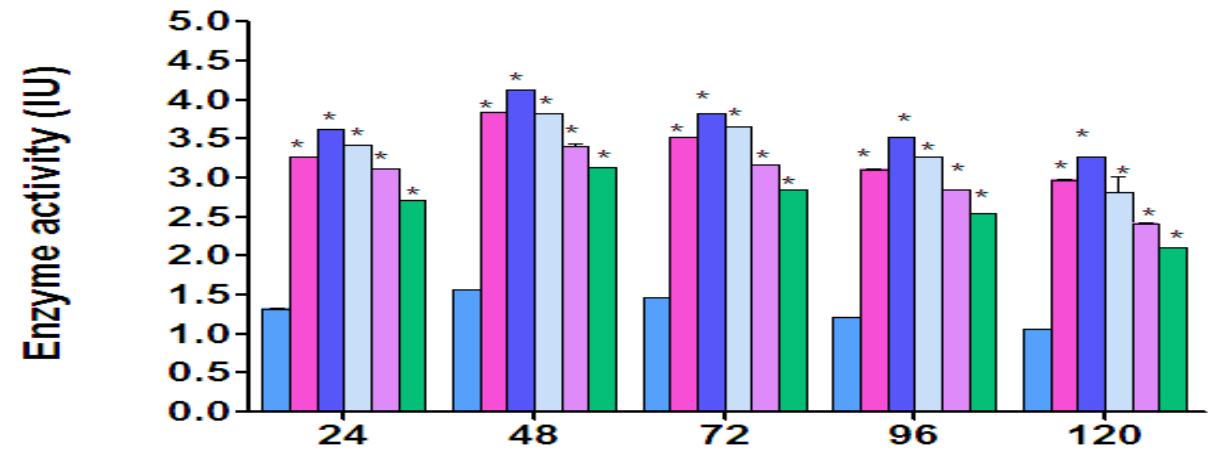

Fermentation time (hrs)

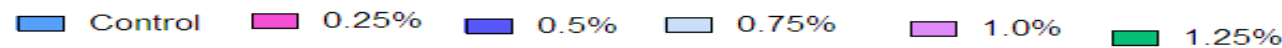

Fig. 8 Effect of Di-ammonium hydrogen phosphate on the production of L-asparaginase 


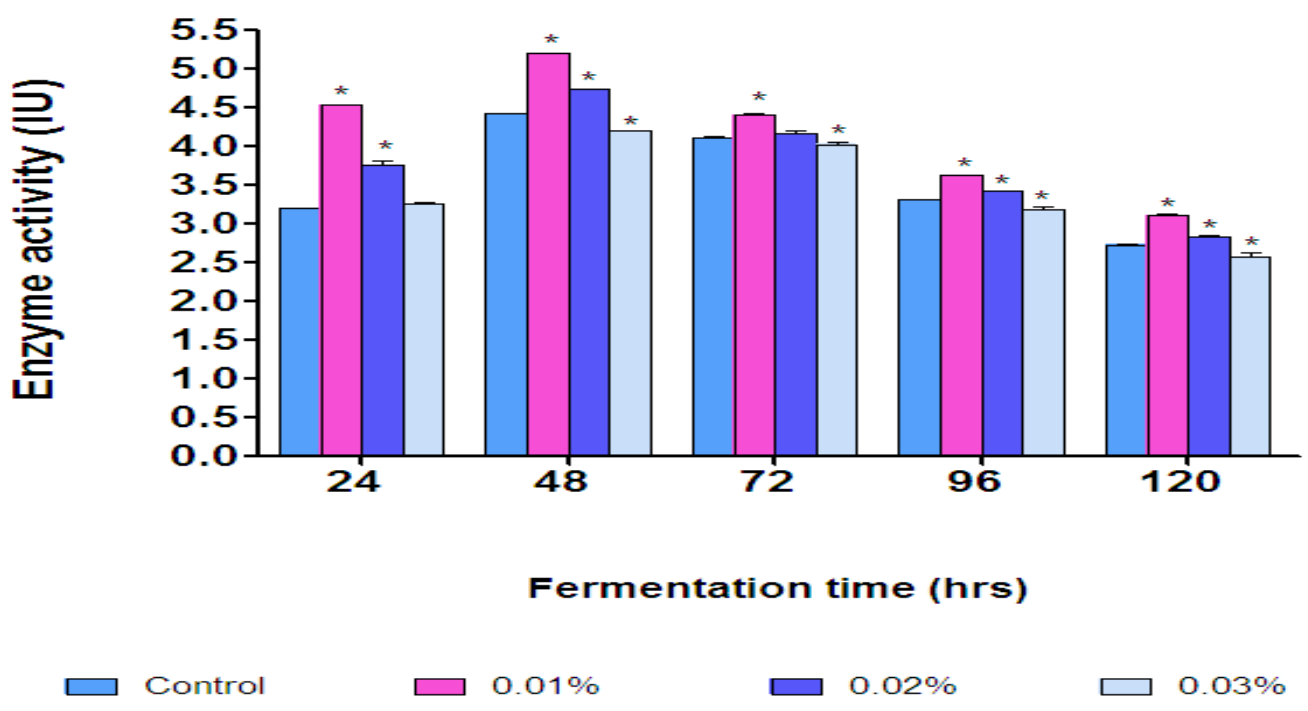

Fig. 9 Effect of Mangenese sulphate on the production of L-asparaginase

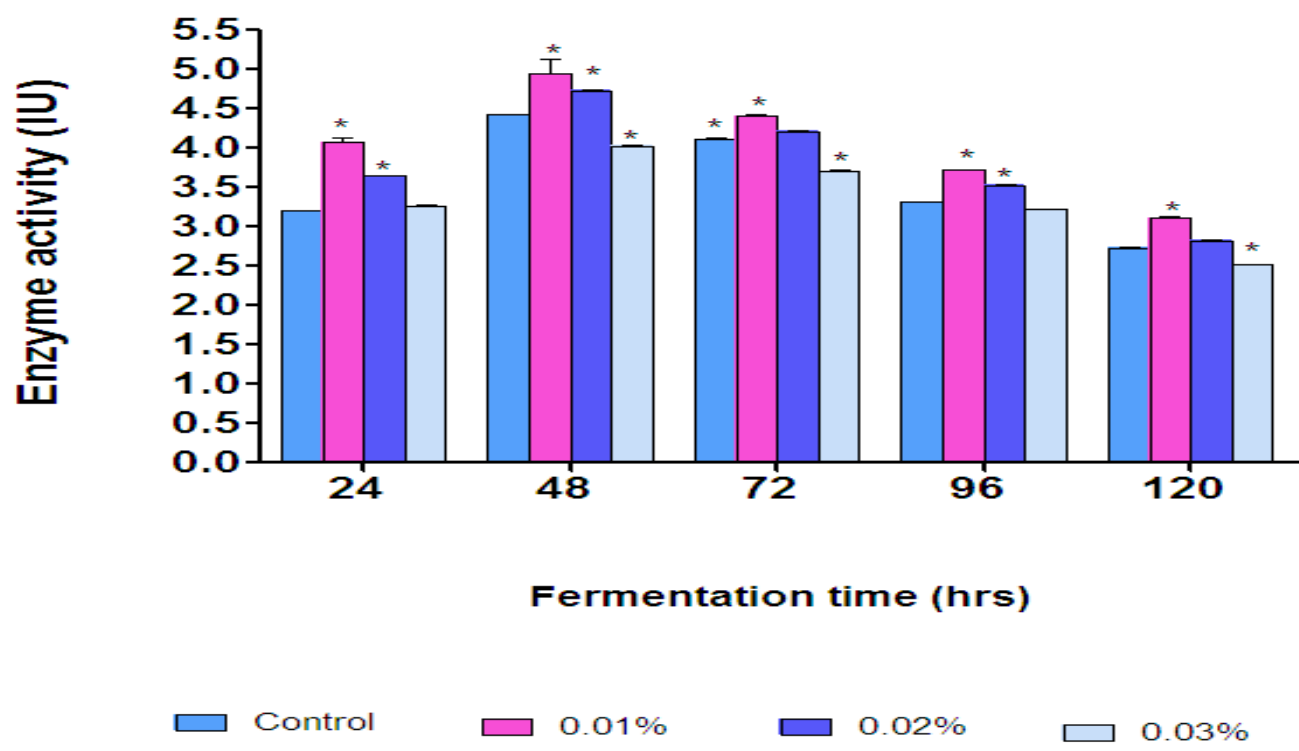

Fig. 10 Effect of zinc sulphate on the production of L-asparaginase 


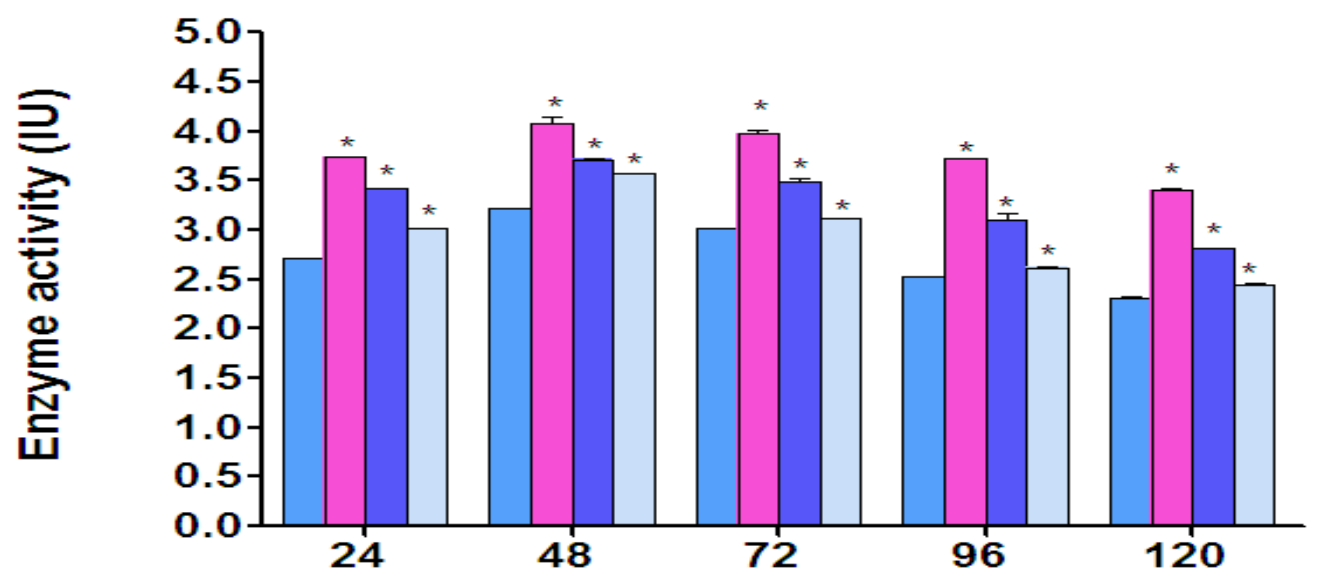

Fermentation time (hrs)

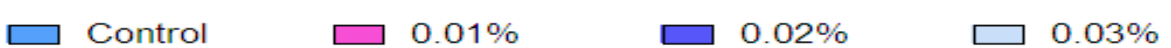

Fig.11 Effect of Magnesium sulphate on the production of L-asparaginase
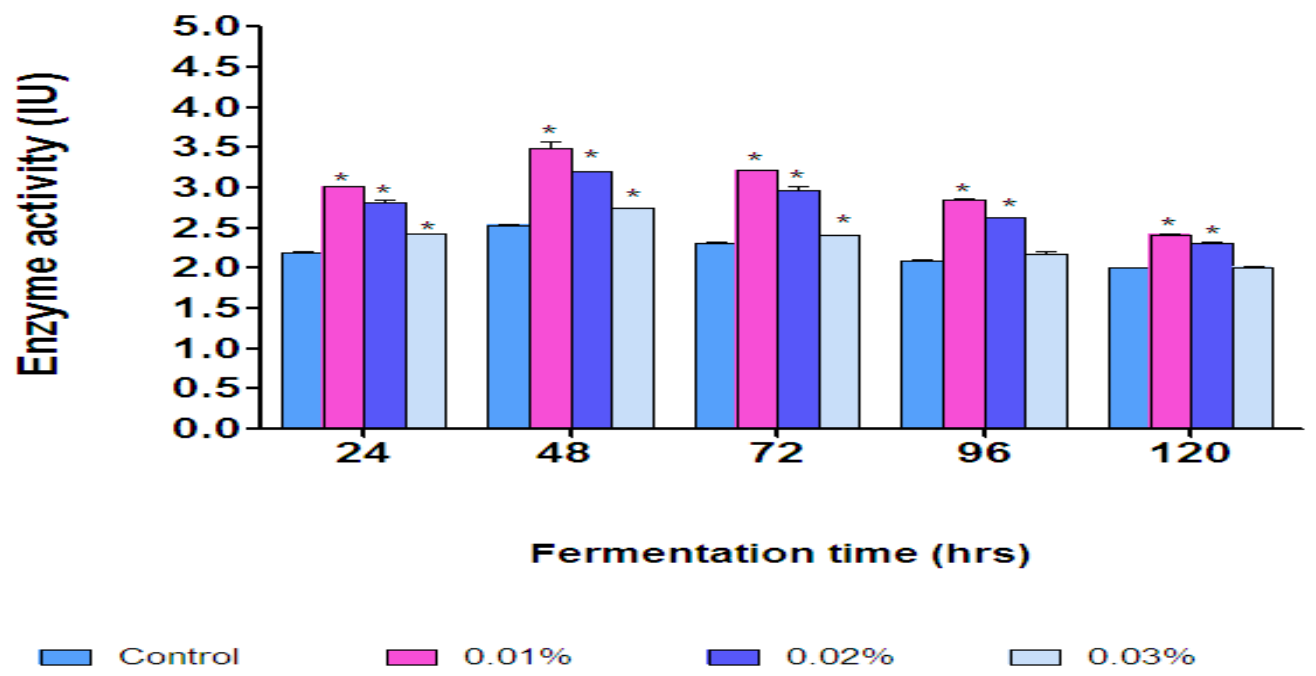

Fig. 12 Effect of copper sulphate on the production of L-asparaginase 